\title{
BAHASA SLANG DALAM SITUASI KOMEDI (SITKOM) THE FRESH PRINCE OF BELL AIR
}

\author{
Fiza Asri Fauziah Habibah \\ Universitas Bina Sarana Informatika Jakarta \\ 08979555658 \\ Email: fiza.ffz@bsi.ac.id
}

Received August 14, 2019, Revised September 3, 2019, Approved November 19, 2019

\begin{abstract}
ABSTRAK
Tujuan penulisan artikel ini adalah untuk mengetahui pemakaian bahasa slang beserta bentuknya yang terdapat dalam Sitkom Amerika The Fresh Prince of Bel Air. Metode yang digunakan dalam penelitian ini adalah metode deskriptif kualitatif yaitu mendeskripsikan hal-hal yang berkaitan dengan masalah yang ditemukan dalam sumber data. Untuk ancangan analisis, penulis menggunakan teori dari Amrullah (2017) dalam bukunya yang berjudul Slang Bahasa Inggris di Dunia Maya. Artikel ini berfokus untuk menganalisis dialog dalam penggalan episode 24 season 4 yaitu Papa's got a brand new excuse. Will, sang pemeran utama, merepresentasikan seorang kulit hitam berbahasa Inggris Afrika Amerika (African American Vernacular English) yang sarat dengan bahasa slang dalam berkomunikasi. Hasil penelitian menunjukkan bahwa terdapat bahasa slang dalam bentuk: 1) kata dasar, dengan kelas kata nomina, verba, ajektiva, adverbial, interjeksi, dan pronomina; 2) frasa, dengan kelas kata frasa nomina dan frasa verba; dan 3) kalimat, yang terdiri dari kalimat tidak lengkap.
\end{abstract}

Kata kunci: Bahasa Slang, Bentuk Slang, Sitkom

\begin{abstract}
This article aims at describing the slang words and their types in American sitcom "The Fresh Prince of Bel Air". The method of the research employs qualitative descriptive which is describing some matters relating to the problem found in the data source. The writer uses Amrullah's theory (2017) in his book "Slang Bahasa Inggris di Dunia Maya" in analizing the slang words. This article focuses to analyze the small part of "Papa's got a brand new excuse"dialog in the sitcom The Fresh Prince of Bel Air,season 4, episode 24. Will, the main character, represents the black urban who speaks African American Vernacular English which is loaded with slang words.. The result shows the existence of slang words in the sitcom The Fresh Prince of Bel Air in the form of: 1) base words, which comprises of noun, verb, adjective, adverb, interjection, and pronoun; 2) phrases, which comprises nominal phrase and verbal phrase; 3) sentences, which comprises uncompleted sentences.
\end{abstract}

Key Words: Slang Words, Types of Slang, Sitcom

\section{PENDAHULUAN}

\section{Latar belakang}

Bahasa memiliki peran yang sangat penting. Bahasa menjadi alat yang paling efektif dalam setiap aktivitas komunikasi. Setiap manusia memerlukan bahasa agar dapat menyampaikan apa yang ada di dalam fikirannya. Dalam pemakaiannya, bahasa menjadi sangat beragam. 
Jurnal Pujangga Volume 5, Nomor 2, Desember 2019

ISSN P 2443-1478

ISSN E 2443-148

Keragaman bahasa sangat bergantung pada kebutuhan dan tujuan komunikasi. Seiring dengan majunya peradaban dunia, banyak cara yang dipilih pemakai bahasa dalam berkomunikasi.

Bahasa Inggris merupakan salah satu bahasa yang digunakan di berbagai Negara. Bahkan di sebagian negara, bahasa Inggris menjadi bahasa kedua bagi masyarakatnya. Peran bahasa Inggris sebagai bahasa internasional sangat penting untuk berbagai sektor yang ada.

Bahasa dikenal dalam dua bentuk, yaitu bahasa baku dan tidak baku. Bahasa baku adalah bahasa yang memnuhi kaidah berbahasa yang baik dan benar, biasanya digunakan dalam situasi yang formal atau resmi. Bahasa yang tidak baku adalah bahasa yang tidak memenuhi kaidah bahasa yang baik dan benar. Bahasa tidak baku biasanya digunakan dalam situasi tidak formal atau santai. Adapun bahasa yang baik adalah bahasa yang situasional, artinya penggunaan bahasa disesuaikan pada situasi ketika penutur dan mitra tutur berbicara.

Penggunaan bahasa tidak baku dikenal dengan istilah Slang. Bahasa Slang muncul akibat pengaruh lingkungan. Bahasa Slang terbentuk berdasarkan konvensi di antara pengguna bahasa. Yang dimaksud konvensi adalah kesepakatan. Artinya para pengguna bahasa telah menyepakati untuk menggunakan Bahasa Slang tersebut dalam lingkungan pergaulannya.

Fromkin (1997: 283) menyatakan bahwa penggunaan Bahasa Slang bervariasi dari satu daerah ke daerah lain. Oleh karena itu, bahasa Slang di Amerika akan berbeda dengan bahasa Slang di Inggris atau Australia. Setiap daerah atau negara memiliki bahasa Slang mereka sendiri. Seperti yang kita ketahui, ada Slang Amerika, Slang Inggris, Slang Australia, dan Slang Kanada. Dalam hal ini penulis ingin menyelidiki bahasa Slang dalam situasi komedi (sitkom) Amerika yang terkenal tahun 90'an berjudul The Fresh Prince of Bel Air.

Sitkom berjudul The Fresh Prince of Bel Air yang diperankan oleh William Smith merupakan serial televisi yang ditayangkan oleh jaringan televisi Amerika Serikat bernama National Broadcasting Company (NBC). Berlatar kawasan elit bernama Bel Air yang terletak di Los Angeles, Amerika Serikat, serial ini menggambarkan kehidupan orang orang berlatar belakang kulit hitam yang sarat dengan Bahasa Slang dalam percakapan sehari-harinya. Will Smith pemeran utama dari sitkom ini digambarkan sebagai seorang remaja berbakat dan berkarakter santai dari bagian barat Filadelfia. Sitkom The Fresh Prince of Bel Air ini menggunakan berbagai aksen bahasa Inggris untuk mengilustrasikan asal, jender atau status sosial dari karakter tententu. 


\section{Rumusan Masalah}

Berdasarkan latar belakang di atas, masalah yang akan dikaji di dalam artikel ini dirumuskan sebagai berikut.

1. Bahasa Slang apa sajakah yang terdapat dalam Sitkom The Fresh Prince of Bel Air?

2. Bentuk Slang apa sajakah yang terdapat dalam Sitkom The Fresh Prince of Bel Air?

\section{Tujuan Penelitian}

Sesuai dengan rumusan masalah yang dikemukakan, tujuan penelitian ini adalah sebagai berikut.

1. Mengidentifikasi Bahasa Slang dalam Sitkom The Fresh Prince of Bel Air.

2. Menganalisis bentuk Slang dalam Sitkom The Fresh Prince of Bel Air.

\section{Tinjauan Pustaka}

\section{Pengertian Slang}

Slang merupakan jenis variasi bahasa. Variasi bahasa mengacu pada segala bentuk tutur kata yang digunakan oleh pembicara atau sekelompok pembicara. Fitur linguistik dari variasi bahasa dapat ditemukan pada tingkat leksikal, fonologi, morfologi, atau sintaksis bahasa (Izmaylova: 2017).

Slang is kind of speech variety. Speech variety, or language variety, refers to any distinguishable form of speech used by a speaker or a group of speakers. Linguistic features of a speech variety can be found at the lexical, the phonological, the morphological, or the syntactical level of the language (Izmaylova: 2017).

A. Chaer dan L. Agustina (2010: 67) menjelaskan bahwa yang dimaksud dengan slang adalah variasi sosial yang bersifat khusus dan rahasia. Artinya, variasi ini digunakan oleh kalangan tertentu yang sangat terbatas, dan tidak boleh diketahui oleh kalangan di luar kelompok itu. Oleh karena itu, kosakata yang digunakan dalam slang ini selalu berubah ubah.

Menurut Alwasilah (1985: 56) slang adalah kata-kata baru yang memperkaya kata bahasa dengan mengkomunikasikan kata-kata lama dengan makna baru, jarang dengan kata yang sama sekali baru, tapi sering dengan kata lama dengan arti yang sama sekali baru. 
Jurnal Pujangga Volume 5, Nomor 2, Desember 2019

ISSN P 2443-1478

ISSN E 2443-148

Dari ketiga definisi diatas dapat disimpulkan bahwa slang merupakan variasi bahasa tidak baku yang digunakan oleh sekel k orang untuk berkomunikasi dengan tujuan kelompok diluar mereka tidak memahaminya. Bahasa slang biasanya menggunakan kata-kata baru dan bersifat temporal atau berubah-ubah.

\section{Penggunaan Slang}

Fishman (1971) mendefinisikan penggunaan slang sangat sementara, slang tidak memiliki definisi yang tepat serta pasti dan hanya bisa dipahami oleh kelompok tertentu atau masyarakat tempat bahasa tersebut berasal. Fishman menjelaskan bahwa karakteristik slang adalah pengurangan struktur bahasa secara sintaks atau juga dengan singkatan yang meliputi penghilangan segmen, penggunaan inisial, penghilangan nama, dan penambahan kosakata yang tidak biasa. Dumas dan Lighter (1978) berpendapat bahwa sebuah ungkapan bisa dikatakan "slang sejati" jika memenuhi setidaknya dua dari kriteria berikut.

1. Menurunkan situasi dari percakapan atau tulisan formal atau serius; Dengan kata lain, bisa juga dianggap sebagai "penyalahgunaan kata yang membingungkan"

2. Penggunaannya menyiratkan bahwa pengguna terbiasa dengan apa pun yang disebut, atau dengan kelompok orang yang mengerti dan juga menggunakan istilah tersebut.

3. Kata tersebut adalah istilah tabu dalam percakapan biasa yang digunakan oleh orang orang dengan status sosial yang lebih tinggi atau memiliki tanggung jawab yang lebih besar.

4. Menggantikan "kata sinonim yang biasa digunakan". Hal ini dilakukan untuk menghindari ketidaknyamanan yang disebabkan oleh kebiasaan.

Fromkin (1997: 283) menyatakan bahwa penggunaan slang bervariasi dari satu daerah ke daerah lain. Karena itu, slang di Amerika akan berbeda dengan slang di Inggris atau Australia. Setiap daerah atau negara memiliki bahasa slang mereka sendiri. Seperti yang kita ketahui, ada bahasa slang Amerika, slang Inggris, dan slang Australia.

\section{Bentuk Slang}

\section{A. Slang Berbentuk Kata}

Slang yang berbentuk kata dapat dibedakan menjadi dua jenis, yaitu slang yang berupa kata dasar dan slang yang berupa kata turunan.

1. Slang Berbentuk Kata Dasar

Kata dasar merupakan bentuk dari sebuah morfem yang dianggap paling umum dan paling tidak terbatas (Kridalaksana, 2008:33). Dalam bahasa Inggris dikenal adanya 
kelas kata yang dibagi ke dalam beberapa jenis sesuai dengan fungsi sintaksis di dalam sebuah kalimat. Pembagian kelas kata menurut Morley (dalam Amrullah. 2017: 20) didasarkan atas pembagian secara gramatikal tradisional. Morley membagi kelas kata menjadi: 1) kata benda atau noun, 2) kata kerja atau verb, 3) kata sifat atau ajektiva, 4) kata keterangan atau adverbial, 5) kata depan atau preposision, 6) kata hubung atau conjunction, 7) interjeksi atau interjection, 8) artikel atau article, 9) kata ganti atau pronoun, dan 10) kata penanda atau determiner.

a. Nomina

Morley dalam (Amrullah. 2017: 20) menyebutkan nomina adalah kelas kata yang biasanya dapat berfungsi sebagai subjek, objek, dan pelengkap. Nomina kadang disamakan dengan kemampuannya untuk berinfleksi serta untuk dilekati dengan artikel serta penanda jumlah.

b. Verba

Verba merupakan kelas kata yang mengekspresikan proses sesuatu atau tindakan yang dilakukan oleh pelaku. Proses tersebut meliputi aksi, rekaman peristiwa, serta kondisi suatu keadaan tertentu. Sedangkan definisi secara gramatikal, kata kerja memiliki fakta bahwa bentuk mereka bisa mengalami infleksi untuk penanda tense, aspect, mood, voice, serta bentuk persona dari subjek yang sesuai (Morley dalam Amrullah. 2017: 23).

c. Ajektiva

Ajektiva merupakan kelas kata yang berfungsi untuk memberi ciri atau atribut pada kata benda. Dalam bahasa Inggris, kemunculan ajektiva dapat berada di depan unsur pusat atau prenominal dan muncul setelah postnominal (Morley dalam Amrullah. 2017: 25).

d. Adverbia

Adverbia berfungsi sebagai kata yang menerangkan keadaan verba, yang menjelaskan pertanyaan dari kata how, why, when, dan where (Morley, 2000: 40).

e. Preposisi

Preposisi adalah kata yang berfungsi untuk menujukkan hubungan antara objek dengan bagian lain di dalam kalimat. Preposisi ini bersama dengan objeknya menerangkan verba, nomina, dan ajektiva. Sebagian besar preposisi dalam Bahasa Inggris berada di depan elemen kompletif, artinya mereka 'diposisikan', tetapi 
hanya dalam beberapa contoh mereka berada setelah elemen kompletif (Morley, 2000: 42).

f. Konjungsi

Konjungsi diklasifikasikan ke dalam dua subtype: konjungsi koordinasi dan subordinat. Konjungsi koordinasi, juga disebut koordinator atau penghubung, menghubungkan unit dengan status tata bahasa yang sama, terutama klausa dengan klausa (utama dengan utama, atau bawahan dengan bawahan) dan frasa dengan frasa. Konjungsi subordinat, juga disebut subordinator atau pengikat, memperkenalkan klausa bawahan dan menggabungkan atau mengikat klausa yang status tata bahasanya tidak setara, misalnya klausa bawahan dengan klausa utama, atau satu klausa bawahan dengan klausa bawahan lain yang langsung menjadi atasan (Morley, 2000: 43).

g. Interjeksi

Interjeksi diartikan sebagai kata atau kata-kata yang digunakan untuk mengungkapkan eksklamasi atau reaksi emosi penutur tetapi tidak ada makna leksikal di dalamnya (Morley dalam Amrullah, 2017:26).

h. Artikel

Artikel digunakan untuk menandai kekhususan, generalisasi atau keumuman referensi dalam sebuah unit yang menunjukkan nomina tertentu. Biasanya unit tersebut telah disebutkan atau bisa dikenali berdasarkan situasi (Morley, 2000: 45).

\section{i. Pronomina}

Pronomina atau kata ganti digunakan sebagai kata pengganti yang merujuk atau mengacu pada kata benda lain (Morley, 2000: 45-46).

\section{Slang Berbentuk Kata Turunan}

Kata turunan adalah kata yang berasal dari bentuk dasar yang telah mengalami proses morfologis tertentu sesuai dengan kaidah bahasa. Proses morfologis dapat diartikan sebagai proses pembentukan kata-kata dengan menghubungkan morfem satu dengan morfem yang lainnya. Proses morfologis dapat dibedakan menjadi tiga hal, yakni proses pembubuhan afiks, proses pemajemukan atau komposisi, serta proses perulangan atau reduplikasi (Kridalaksana dalam Amrullah, 2017: 28). 
a. Kata Berafiks

Afiksasi adalah proses pelekatan morfem terikat - yang bukan merupakan leksem dengan bentuk dasar untuk memproduksi bentuk kata. Afiks dapat dikelompokkan menjadi tiga posisi pada sebuah bentuk dasar, yakni prefix yang melekat sebelum bentuk dasar, sufiks yang melekat setelah bentuk dasar, serta infiks yang melekat di tengah bentuk dasar (Bauer dalam Amrullah, 2017: 29)

b. Kata Majemuk

Kata majemuk atau komposisi merupakan salah satu proses pembentukan kata yang umum terjadi di berbagai bahasa yang ada di dunia. Kridalaksana dalam Amrullah (2017:31-32) menjelaskan bahwa kata majemuk merupakan gabungan leksam dengan leksem yang seluruhnya berstatus sebagai kaya yang mempunyai pola fonologis, gramatikal, dan semantic yang khusus menurut kaidah bahasa yang bersangkutan, pola khusus tersebut membedakannya dari gabungan leksem yang bukan kata majemuk.

c. Reduplikasi

Proses reduplikasi kata termasuk proses morfemis yang sering terjadi pada berbagai bahasa di dunia. Katamba dalam Amrullah (2017: 34-35) menjelaskan bahwa reduplikasi terbatas pada pengulangan bagian kata yang memiliki tujuan derivasi maupun infleksi.jenis dari reduplikasi bisa berupa pengulangan morfem asal, pengulangan morfem asal dengan perubahan vocal dan fonem lainnya, pengulangan silabel pertama, pengulangan akhir kata, serta pengulangan morfem asal hingga dua kali (Verhaar dalam Amrullah, 2017: 34-35).

\section{B. Slang Berbentuk Frasa}

Morley dalam Amrullah (2017: 37) menyebutkan frasa merupakan kelompok satu kata atau lebih yang fokus pada elemen UP dan bersama-sama membentuk peran gramatikal dimana pada kondisi yang lain frasa tersebut dapat diekspresikan dengan satu kata saja. Perbedaan frasa dengan kata majemuk ialah pada titik tekan, dimana kata majemuk menekankan pada makna akhir sedangkan frasa menekankan pada UP.

\section{Frasa Nomina}

Frasa nomina merupakan jenis frasa yang unsur pusatnya berupa kata benda atau kata ganti. Unsur pusat tersebut secara khusus diawali, dimodifikasi atau ditandai dengan artikel, frasa genitive, kata ganti, kata sifat, atau kata benda lain, dan mungkin juga 
diikuti oleh frasa preposisi atau klausa subordinatif (Morley dalam Amrullah, 2017: 37).

2. FrasaVerba

Frasa verba merupakan jenis frasa yang memiliki UP berupa kata kerja yang dapat diawali dengan kata kerja bantu atau partikel. Selain itu frasa verba juga dapat diikuti dengan partikel adverbial (Morley:55).

3. Frasa Ajektiva

Morley (2000:55) memaparkan bahwa frasa ajektiva merupakan frasa yang memiliki sifat sebagai UP, dapat diawali dengan kata keterangan atau juga dapat diikuti kata keterangan, frasa preposisi, atau klausa subordinatif. Posisi dari frasa ajektiva dapat terletak setelah be atau memodifikasi kata benda.

\section{Slang Berbentuk Kalimat}

1. Kalimat Lengkap

Kalimat lengkap adalah kalimat yang memiliki keseluruhan elemen. Sebagaimana diungkapkan oleh Bloomfield dalam Amrullah (2017: 44) bahwa kalimat lengkap atau kalimat penuh merupakan struktur kalimat yang memiliki pola actor-action phrase, atau dapat dikatakan kalimat yang memiliki subjek dan predikat.

2. Kalimat Tidak Lengkap

Kridalaksana dalam Amrullah (2017: 42) menyebut kalimat tak lengkap sebagai kalimat minor, yakni kalimat yang dipakai secara terbatas, seperti pada panggilan, salam, judul, motto, dan sebagainya. Struktur dari kalimat minor ini terkadang tidak memiliki subjek atau predikat.

\section{Sinopsis Sitkom The Fresh Prince of Bell Air}

Papa's got a brand new excuse adalah penggalan episode 24 Season 4 dari sitkom berjudul The Fresh Prince of Bell Air. Sitkom ini ditulis oleh David Zuckerman dan Bill Boulware, dan disutradarai oleh Shelley Jensen.

Will bersatu kembali dengan ayahnya, Lou, setelah 14 tahun tidak bertemu dengannya. Ayahnya muncul penuh dengan rencana untuk menghabiskan waktu dengan Will. Tetapi rencana tersebut tidak pernah terwujud. 
ISSN P 2443-1478

ISSN E 2443-148

Ketika Will berjalan menghampiri ayahnya, Lou sang ayah mencoba menghindar dan pergi keluar tanpa mengucapkan selamat tinggal. Will pun menyadari apa yang terjadi. dengan tenang Will melepaskan ayahnya, memanggilnya dengan nama "Lou" bukan "ayah" dan merelakan ayah keluar dari hidupnya. Pada awalnya Will tampak baik-baik saja ketika Lou, sang ayah, meninggalkannya.

Pada akhirnya Will melontarkan kata-kata kasar tentang bagaimana dia tumbuh dan belajar melakukan banyak hal tanpa Lou dan bagaimana dia akan terus menjalani hidupnya dan menjadi sukses tanpa Lou sebelum dia mulai menangis dan bertanya kepada Phillip mengapa Ayah tidak menginginkannya. Dia dan Paman Phil saling berpelukan menangis.

\section{METODE PENELITIAN}

Penelitian ini menggunakan pendekatan deskriptif kualitatif. Data dikumpulkan dari naskah sitkom The Fresh Prince of Bel Air. Adegan yang dianalisis adalah episode Papa's Got A Brand New Excuse yang merupakan episode 24, season 4. Analisis data dilakukan berdasarkan teori dari Amrullah dalam buku Slang Bahasa Inggris di Dunia Maya. Data yang telah dikumpulkan kemudian diklasifikasi untuk mencari bentuk dari kata-kata slang yang ditemukan. Data yang telah terkumpul dianalisis dan dipresentasikan menggunakan metode induktif, kemudian dibuat kesimpulan tentang makna tersebut menggunakan kamus A Dictionary of Slang and Unconventional English (Partridge: 1984).

\section{PEMBAHASAN}

Berikut ini hasil klasifikasi slang berdasarkan data yang penulis temukan dalam sitkom The Fresh Prince of Bel Air.

\section{Bentuk-Bentuk Slang}

\section{A. Slang Berbentuk Kata}

Slang Berbentuk Kata Dasar

1. Nomina

Berikut ini daftar kata dasar slang yang berbentuk nomina.

Slang

Daddy-O

\section{Makna}

seorang ayah 
Jurnal Pujangga Volume 5, Nomor 2, Desember 2019

ISSN P 2443-1478

ISSN E 2443-148

Slimmies

panggilan untuk para gadis

Honey

panggilan untuk seorang pacar

(1) Daddy-O

Will: Daddy-O .. What's Up?

Lou: Wil .. Man, I'm glad you're here.

Daddy-O adalah kata yang bermakna father "ayah".

(2) Slimmies

Will: The slimmies this summer come to class wearing next to nothing

Simmies adalah kata lain dari girls "para gadis", yang merupakan kata slang jalanan yang popular tahun 90 -an.

(3) Honey

Will: I'll marry a beautiful honey, have a bunch of kids and be a better father than he ever was.

Honey umumnya diartikan madu jika ditujukan pada makanan, namun ia mengalami perubahan makna jika digunakan dalam konteks yang berbeda. Dalam hal ini, honey bermakna "sayang”, yaitu panggilan untuk seorang pacar.

2. Verba

Berikut ini daftar kata dasar slang yang berbentuk verba.

$\begin{array}{ll}\text { Slang } & \text { Makna } \\ \text { Gonna } & \text { akan } \\ \text { Ain't } & \text { bukan }\end{array}$

\section{(4) Gonna}

Will: You know what, Uncle Phill? I'm gonna get through college without him.

Gonna merupakan bentuk yang dipendekkan, pelafalan yang sebenarnya berasal dari kata going to.

(5) Ain't

Will: You know what, you ain't got to do nothing, Uncle Phill. It ain't like I'm still

5 years old. Ain't like I'll be sitting upevery night asking my mom.. 
Will: I don't need him for that, because there ain't a thing..

Aint merupakan bentuk yang dipendekkan, terdiri dari kata is not, are not, am not, do not dan does not.

3. Ajektiva

\section{Slang}

Damn

Stupid

\section{Makna}

ungkapan kekesalan

tidak berguna

\section{(6) Damn}

Will: he never ever sent me a damn card.

\section{(7) Stupid}

Will: I just wish I hadn't wasted my money buying this stupid present.

4. Adverbia

Slang

Yeah

Pretty

(8) Yeah

Will: Yeah, whatever. Whatever.

(9) Pretty

Will: And I got pretty good at it too.

\author{
Makna \\ ungkapan persetujuan \\ cukup
}

5. Interjeksi

\section{Slang}

Cool

Hell

(10) Cool

Lou: you understand?

Will:Yeah. That's cool.

Cool merupakan ungkapan yang artinya sama dengan it's okay, don't worry, atau there's no problem with that. 
Will mengucapkan I'm cool with that untuk mengungkapkan bahwa dia baik baik saja dengan keadaannya sekarang dan menyetujui yang dikatakan ayahnya meskipun perasaannya berbanding terbalik dengan perkataannya.

(11) Hell

Will: To hell with him! I didn't need him then and I didn't need him now

Hell Merupakan ungkapan yang digunakan untuk memberikan penekanan yang kuat. Biasanya untuk menunjukkan ketidaksukaan seseorang. Will menggunakan kata hell sebagai ungkapan kekesalan terhadap ayahnya.

6. Pronomina

Slang

What's Up

\section{Makna}

Apa kabar

(12) What's Up

Will: Daddy-O .. What's Up?

Lou: Wil .. Man, I'm glad you're here.

What's up merupakan kata ganti interogatif yang biasa digunakan untuk mencari klarifikasi atau jawaban. Padanan kata sari what's up adalah how are you.

B. Slang Berbentuk Frasa

1. Frasa Nomina

\section{Slang}

Stupid present

Damn card

Beautiful honey

Works out

\author{
Makna \\ hadiah yang tidak berguna \\ kartu sialan \\ cewek cantik \\ omong kosong
}

\section{(13) Stupid present}

Will: I just wish I hadn't wasted my money buying this stupid present.

Stupid secara harfiah diartikan bodoh atau tolol. Tetapi dalam urban dictionary, stupid bisa bermakna annoying atau irritating "menjengkelkan". Dalam konteks ini, supid 
present tidak diartikan sebagai hadiah yang bodoh melainkan hadiah yang tidak berguna.

(14) Damn card

Will: he never ever sent me a damn card.

Damn digunakan untuk memberi penekanan pada saat marah. Damn card digunakan sebagai ungkapan kutukan terhadap sesuatu sebagai akibat dari rasa marah.

(15) Works out

Will: Actually, this works out better for me.

Work out dalam konteks disini berfungsi sebagai frasa nomina yang diartikan sebagai to take a shit "omong kosong".

2. Frasa Verba

\section{Slang Makna}

Iron out meluruskan

(16) Iron out

Lou: Look, I'll call you next week and we'll iron out the details. Okay?

Iron out merupakan frasa verba yang terdiri dari kata iron dan out yang bermakna straighten out (meluruskan).

\section{Slang Berbentuk Kalimat}

Kalimat Tidak Lengkap

\section{Slang}

Know what I'm saying?

\section{Makna}

Mengerti maksud saya?

\section{(17) Know what I'm saying}

Know what I'm saying merupakan bentuk yang dipendekkan dari frase do you know what I am saying. Ungkapan ini mempunyai makna yang sama dengan (do you) know what I mean? apa kau mengerti apa maksud saya?".

Ungkapan ini digunakan untuk menanyakan apakah seseorang setuju dengan kita, atau yang lebih penting, apakah mereka mengerti apa yang kita katakan. 
Jurnal Pujangga Volume 5, Nomor 2, Desember 2019

ISSN P 2443-1478

ISSN E 2443-148

\section{SIMPULAN}

Berdasarkan pada paparan analisis, maka dapat disimpulkan sebagai berikut.

Terdapat tiga bentuk slang dalam sitkom The Fresh Prince of Bel Air episode Papa's got a brand new excuse yaitu, 1) bentuk kata dasar yang terdiri dari nomina, verba, ajektiva, adverbia, interjeksi, dan pronomina; 2) bentuk frasa yang terdiri dari frasa nomina dan frasa verba; dan 3) bentuk kalimat yang terdiri dari kalimat tidak lengkap. 


\section{DAFTAR PUSTAKA}

A. Chaer dan Agustina, Leonie. 2010. Sosiolinguistik Perkenalan Awal. Jakarta: Rineka Cipta.

Alwasilah, Chaedar. 1990. Sosiologi Bahasa. Angkasa: Bandung.

Amrullah, Latif. 2018. Slang Bahasa Inggris di Dunia Maya. Yogyakarta: Gadjah Mada University Press.

Bloomfield, L. 1933. Language. New York: Reinehart \& Winston, INC.

Dumas, Bethany K; Jonathan Lighter. 1978. Apakah Slang Kata untuk Ahli Bahasa?. Pidato Amerika . 53 (5): 14-15

Fishman, J, A. 1972. The Sociology of Language. Marrickville: Holt Rinehart and Winston.

Fromkin, Victoria dan Robert Rodman. 1998. An Introduction to Language, Edisi ke-6. Orlando: Harcourt Brace College Publisher.

Guth, P. H. 1961. Concise English Handbook. California: Wadsworth Publishing Company, INC.

Izmaylova GA, Zamaletdinova GR, Zholshayeva MS. Linguistic and Social Features of Slang. It J Sci Stud 2017;5(6):75-78.

Kridalaksana, Harimurti. 2008. Kamus Linguistik. Jakarta: Gramedia Pustaka Utama.

Morley, G. David. 2000. Syntax in Functional Grammar: An Introduction to Lexicogrammar in Systemic Linguistics. London: Continuum.

Tien, Tan Siok. 2018. KAMUS SLANG AMERIKA For Daily American English Conversation. Yogyakarta: C.V. ANDI OFFSET.

Http.//www.urbandictionary.com (diakses 15 September 2019) 